\title{
OSIEMNASTOWIECZNY MELODRAMAT O NAWRÓCENIU ŚW. AUGUSTYNA
}

Wóród starodruków-poloników o tematyce patrystycznej sa dwa utwory literackie poświęcone nawróceniu św. Augustyna: Marii Antonil Walpurgis - "La conversione di Sant'Agostino" 1 jego polskie tłumaczenie, dokonane przez Józefa Andrzeja Załuskiego - "Nawrócenie św. Augustyna". Pierwszy z nich jest dostępny w zbiorach Biblioteki Jagiellońskiej w Krakowie/dział starych druków, sygnatura 390652 I/, drugi zaś w tejże bibliotece /sygnatura $30229 \mathrm{I} /$ oraz w dziale starodruków Biblioteki Narodowej w Harszawie /sygnatura XVIII.2.637/.

Autorka oryginału włoskiego Maria Antonia W a 1 p $u r$ g 1 s ur. w 1724 r. w Monachium była najstarsza córka bawarskiego księcia Karola Alberta, późniejszego cesarza Karola VII /Wittelsbacha/ 1 najmłodszej córk1 cesarza Józefa I. Swojej babce cesarzowej Wilhelminie Amalii/żonie Józefa I/ zawdzięczała dobrą znajomość języka łacińskiego i włoskiego. Muzyki, do której juz od najwcześniejszych lat zdradzała zdolności, uczyz ja znany $t$ lubiany ówczesny kompozytor G. Ferrandini /1710-1791/, będący kapelmistrzem na dworze bawarskim. W 1747 . wyszła za mąz za słabego zdrowiem, ale silnego duchem, kochającego sztukę 1 Iiteraturę, księcia saskiego Fryderyka Chrystiana, który po śmierci swego ojca Augusta III - króla polskiego /zm• 1763 r。/ objął rzady w Saksonil. Młody władca powierzył swej żonie sprawy IInansowe 1 piecze nad manufaktura porcelany w Míni: Maria Antonia, mając w ręku skarb państwa, wyraźnie przyczyniała się do rozszerzania i umacniania Akademii Sztuk pod patronatein Hagedornów. Iszystkie jednak plany zostały przekreślone wraz ze émierci dz małżonka, Fryderyka Chrystiana, w imieniu którego przez ostatnie lata piastowała rząuy.

Czterdziestoletnia Maria Walpurgis zyła jeszcze ponad szesnaście lat wydatnie poplerając naukę 1 sztuke, oddarata się równiéz praktykom poboźnym 1 wychowaniu dziec1. Po oojęciu w 1768 r. waddzy po ojcu przez najstarszeğo syna Fryderyka Augusta 1 podniesieniu przezeń pinansowego uposazenia matki, mogła ona oubyć kilka podróży do Itali1, Akwizgranu, Monachium 
i Berlina, gdzie odwiedziła m.in. Fryderyka II. Zmarła w 1780 roku. Syn Fryderyk August napisaz o niej: "Była gorliwa w wypełnianiu religijnych obowiązków, miłosierną wobec biednych 1 potrzebujących pomocy, biegła w naukach i sztukach, cierpliwa w zajęciach i pracach, ukochaną, czułą i najlepszą matką". Maria Antonia po przybyciu 1747 r. do Drezna, jako zona Fryderyka Chrystiana, zastała tam wspaniały dwór z wysoka kulturą, na którym kwitła muzyka i rozwijało się źcie teatralne. Księżna wniosła nowe życie do muzycznych kręgów dworu i sama wystąpiła z własną twórczością, wykazując wybitna znajomość i biegłośc muzyce, poezji i malarstwie. Wkrótce stała się sławna w całym ówczesnym cywilizowanym świecie. W Saksonil załozyła bibliotekę liczaç ponad 46 tys. woluminów. Była protektorka malarza R. Menga $i$ takich kapelmistrzów, Jak: J. A. Ilasse /16991783/, N. Porpora /1686-1768/, J. G. Naumann /1741-1801/, J. Schuster /1748-1812/ oraz śpiewaczek - R. Mingotti /1722-1808/ 1 G. E. Mary /1749-1833/. Równies jej dwie główne opery "Il trionfo della fedeltá" i "Talestri regina della Amazzoni", skomponowane według założeń P. Metastasia 1 Hassego, zostały przez ówczesnych krytyków wysoko ocenione, przynosząc jej sławę. Opubl1kowane w Lipsku 1756 i 1765 r., podpisane pseudonimem M. A. z dodatkiem E. T. A. P., tj. Erfilinda Talea Pastorella Arcada /pod tym pseudonimem komponowała i pisała poezje/, przesłała w darze Fryderykowi Wielkiemu. Źródło jej tajemniczego pseudonimu stanowił fakt, iż od 1747 r. była członkieın Arkadiów - naukowego towarzystwa w Izymie, gdzie prezentowała swoje włoskie wiersze, przyjmowane z dużym entuzjazmem. Oprócz tego skomponowała sześc arii, dwa okolicznościowe poersaty, muzyke do kantaty dworskiego poety G. Migliavacci i jeden tom tzw. Medytacji. Wiele jej utworów poetyckich zostało opracowanych muzycznie przez dworskich kapelmistrzów: Ilassego, G. A. Historiego/1692-1753/ i Naumanna. Do jej utworów muzyke komponowali także Ferrandini, G. Manna, K. H. Graun, M. Schmidt. Niektóre z nich sama opracowywała muzycznie. Spiewała również główne role w swych operach "Il trionfo..." i "Talestri...". W Monachium w 1740 r. wykonała główną partię solowa w pewnej pastorale, wystawionej dla uczczenia ksiecia Augusta Klemensa z Kolonil. Lubiła zwlaszcza muzyke włosk ą $i$ poezję dramatyczną, co objawialo sie w częstym recytowaniu utworów dramatycznych. Gdy od 1751 r. na ksiazęcych dworach zaczęto grywac Prancuskie komedie, sama przełozyła na 
język francuski "Denetrio" Metastasia. Ceniła szczególnie utwory dranatyczne F. M. Voltaire'a. Starała sie od 1754 r. wprowadzić na scenę niemiecká dobrych aktorów. Nie tylko komponowała 1 śpiewała,lecz także malowała wyisonując m.in. własny portret ofiarowany Fryderykowi Wielkielu, wielokrotnie później kopiowany •

W ramach wyżej scharakteryzowanej twórczości mieści się również ułożone przez nią oratoriub "La conversione di S. Agostino", do którego muzylię skomponował wspomniany już nadworny kapelmistrz Augusta III, J. A. Lasse. Oratorium to zostało wystawione po raz pjerwszy w Dreźnie 28 III 1750 r., w Wielką Sobotę, o godz. 4 po południu w katolickiej kaplicy dworskiej, a następnie w latach 1751, 1752, 1761, 1781, kilkakrotnie powtarzane. Zachowało się wiele wydá́ jego tekstu yo wlosku, niemiecku a także po polsku. Słuchano gro także w Monachium, Berlinie, Lipsku, izymie i innych miejscowościaci.

Oratorium Marii Antoni i lialpurgis przetłumaczył wierszem na język polski referendarz koronny, ks. Józef Andrzej Z a ¥ u s $\mathrm{k}$ i /1702-1774/, późniejszy biskup kijowski /od 1758 r./, który był jednocześnie mecenasem nauki 1 literatury oraz współtwórca znanej Biblioteki Załuskich. Kształcił sie za granica w latach 1716-1723, doktorat praw otrzymał jednak w Akademii Krakowskiej 1724 roku. Od młodości zdradzał skłonności bibliofilskie, gromadził druki i rekopisy.

W jego rozległej spuściźnie literackiej najważniejszą rolę odgrywaja kompendia bibliograficzne. obok nich znane sa m.1n. jego utwory religijne, jak: "Zaślubiente w cierniowym wieńcu dusz pokutujących oblubieńcowi Niebieskiemu" - misterium napisane w $1720 \mathrm{r}$ • dla siostry wizytki z klasztoru warszawskiego, które sam nazywa "melourama", wiersz 1 iryczny "Epithalamium Verbi Divini cum humana natura" / wyd. $1754 \mathrm{r} \bullet /$ oraz kołysanka "Naenia infant11is ad cunas vagientis Jesu" /wyd. $1754 \mathrm{r} \bullet /$, stanowiazce tłumaczenia łacińskich wierszy jezuity Ilieronima Drekseliusza, różne wierszowane modlitwy, pieśni pokutne $i$ akty skruchy /Zebrania rytmów, II, Warszawa 1754/, oratoria i "melodramy", pisane dla dworu saskiego, będące najczęściej tłumaczeniami z włoskiego jak: "Peregrynacje do grobu Chrystusa Pana"/śpiewane w królewskiej kaplicy drezderiskiej w Wielki Piatek $1749 \mathrm{r} \cdot /$, "Grób Chrystusa Pana" /na Wielka Sobote 1749 r./ 1 "Depozycja 
z krzyża Chrystusa Pana" /napisane przez nadwornego poetę królewskiego J. K. Pasquiniego 1 śpiewane po włosku w drezdeńskiej kaplicy wielka Sobote 1744 r., a tłumaczone przez niego w 1752 r. /oraz prezentowane przez nas wystawione po raz pierwszy pod koniec lutego 1751 r. w Kielcach - "Nawrócenie Swiętego Augustyna". Oprócz tego w 1751 r. przetłucsaczył wierszem dwadzieścia dłuźszych rozmyślań ascetycznych /napisane proza no Prancusku przez karmelitankę bosą, księźnę de la Vallière, a przetransponowane na wiersze Prancuskie przez Marie Antonię Walpurgis /pt. "Affekty dusze pokutującej nad XXX Dawidowym Psalmem Pokutnym: Miserere tnei Deus - przez Józefa w drodze zawiślnej 1754".

Obok tych utworów dewocyjnych Załuski pozostawił po sobie bogaty zbiór fraszek, pisanych zarówno w modości pt. "Juvenilia to jest kompozycje w młodym wieku pisane", jak i później podczas wygnania /1768-1773/ - pt. "Facecje rymowe" /6365 fraszek/. Tłumaczył ponadto "List XII" 1 "Satyry" /8, 10, 12/ N. Boileau, opublikowane w 1753 r. w Warszawie pt. "Próba pióra nowego poety w trzech starych satyrach" oraz niektóre utwory P. Malezieux. Przekłady Boileau i Malezieux umieszczaja go wśród pisarzy, pragnących rozwijać i dosiconalić literature narodowa opierając się na klasycyzmie francuskim. Największym jednak dziełen literackim była wydana w $1768 \mathrm{r}$. Warszawie pięcioaktowa tragikomedia "Ludzkość 1itująca się, czyli obraz nędzy ludzkiej", stanowiąca pierwszą próbę dranatu mieszczańskiego w Polsce.

Wyżej wymienione utwory świadczą, że problem nawrócenia św. Augustyna, zwaszcza na poczł̨tku XVIII w., stał się popularnym motyweil w artystycznej twórczości teatralnej i muzycznej. Namacalnym tego dowodem jest m.in. wydana za granica antologia pt. "La conversione di S. Agostino" / loma 1705/ przez C. Rotondiego, zawierająca ponad 50 oratoriów 1 kompozycji literackich /por. Biblioteka Watykańska, Ferraioli IV 8620/. W nurcie tej twórczości znajduja się również publikowane tu utwory.

Obydwa zamieszczone niżej oratoria na temat nawrócenia św. Augustyna dzielą się na dwie części. W pierwszej ukazane są wewnętrzne zmagania Augustyna z sanym sobą, proces zmierzający do zerwania z grzesznym życiem i pragnienie powrotu na łono Kościoza katolickiego. W tej wewnętrznej walce wspomagaja go zyczliwe osoby: matka Monika, kapłan Symplicjan, brat Nawigiusz i przyjaciel Alipiusz. Ich wielka troske i życzliwość względem Augustyna wyrażaja trafnie słowa modlitwy chóru kończącej część pierwszą: 


\section{"M1łosierny Boże, Paniel \\ Wsicrześ w tym sercu Twe kochaniel \\ Niech potega ciała wiezzy, \\ Swiat i czarta niech zwycięzy! \\ Ach, zań darmo Krew wylana \\ Niech nie będzie Zbawcy Panal \\ Niech tu dusza jego wsparta \\ Laska ujdzie sideł czartal"}

Druga część natomiast ma charakter bardziej pogodny/szczególnie radosne jest jej zakończenie/, gdyż ukazuje wewnętrzną przenianę Augustyna - jego nawrócenie. Oczywiśc1e, mówiąc "bardziej" pogodny, chcemy podkreślić, że nie cała część jest od samego początku przepojona weselem, poniewaź ukazany jest tu także żal 1 smutek zwiazzany ze zmaganiem się z samym soba i z Bogiem. Niemniej jednak cała ta dranatyczna akcja kończy się wielkim wybuchem radości i dziękczynienia Niebiosom za namrócenie poszukującego prawdy człowieka.

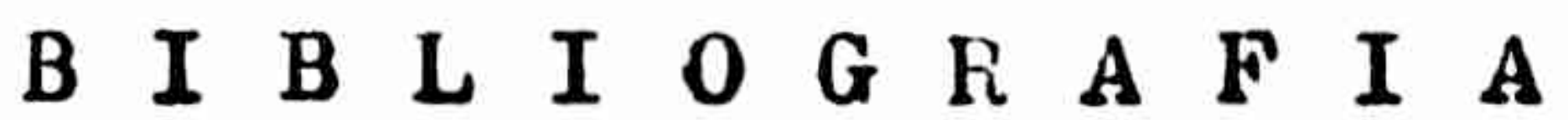

Drama mieszczańska, opr. J. Pawłowiczowa, Warszawa 1955.

M. Furstenau, Maria Antonia Halpurgis, w: Allgemeine Deutsche Biographie, Bd. 20, Leipzig 1084, 371-374.

11. Furstenau, Zur Geschichte der Musik und des Theaters am Hofe zu Dresden, Bd. 2, Dresden 1861, 183-193/ristamp. Leipzig $1971 /$.

R. Gerber, Der Operntypus J. A. llasses und seine textlichen Grundlagen, Leipzig 1925.

J. D. Janocki, Józel Andrzej hrabia na Załuskach Załusk1, Warszawa 1928.

L. Kanieński, Die Oratorien von J. A. Ilasse, Leipzig 1912 .

ii. Konopczyński, August III,PSP I 184 .

C. lotondi, La conversione di S. Agostino, Roma 1705.

G. Sinko, Próby drawatyczne Jozefa Andrzeja Załuskiego, "Pamiętnik Lite racki" 41/1950/792-832.

K. von Weber, Maria Antonia Valpurgis, Churfurstin von Sachsen, Bd. 1-2, Dresden 1857.

UN MELODIIAMMA SETTECENTESCO SULLA CONVEISIONE DI SANT'AGOSTINO /Riassunto/

Sotto tale titolo, dopo una breve introduzione, vengono qui pubblicate due opere pcetiche polacche del setiecento sulla conversione di Sant'Agostino: una di Maria Antonia Walpurg1s, "La conversione $d \dot{x}$ Sant'Agostinu. Oratorio da cantarsi nella Regia Elettoral Cappella di Dresda", Dresda 1750, e un'altra - la sua traduzione polacca di Józep sndrzej Załuski, "Nawrócenie Świętego Augustyna", Kielce 1751. 


\section{A. Walpurgis/}

L A $\quad$ C O N V E H S I O N E D I S A N T'A G O S T I N Oratorio da cantarsi nella liegia telettoral Cappella di Dresda

Interlocutori: S. Agostino, Simpliciano, fionica, Alipio, Navigio, voce, coro. Fu posto in musica dal Sig.r Gio: Adolpo llasse, Primo Maestro di Cappella di S.R.M.

$$
\text { P a } \mathbf{r} \text { e p r i m a }
$$

SIMPLICIANO E MONICA

Simpliciano

Plù non t'affliger tanto,

Madre dolente, e pia:

Il Iiglio tuo già crede;

Già lo spirito è convinto, e 11 core in breve

Camblato ancor sarà.

Monica

Ah' quanto è lieve,

Padre, la mia speranzal Assai m’è noto

Del figlio 11 cor. Troppo 1 profani affetti

Gl' Ingombrano il pensier: ne' rel costumi

Troppo à 11 suo core avvolto,

Altro non sà bramar, che piacer vano.

Ah'! come vuoi ch'io speri,

Che un si perverso core

Possa al puro avampar divino amore?

Simpliciano

E' ver, per tal trionfo

Gran coraggio bisogna:

Ma perché disperar? Non vive in clelo

Una forza maggiore,

Che assisterlo potrà? Speriamo in Dio.

Alle lagrime tue

Ei già molto donò di vera fede

Il santo lume gia diede al tuo figlio;

Esso l'orgoglio suo

A vincer coininciò: Vedrà, che in vano

Presta fede alla legge,

Se resiste ai comandi, 


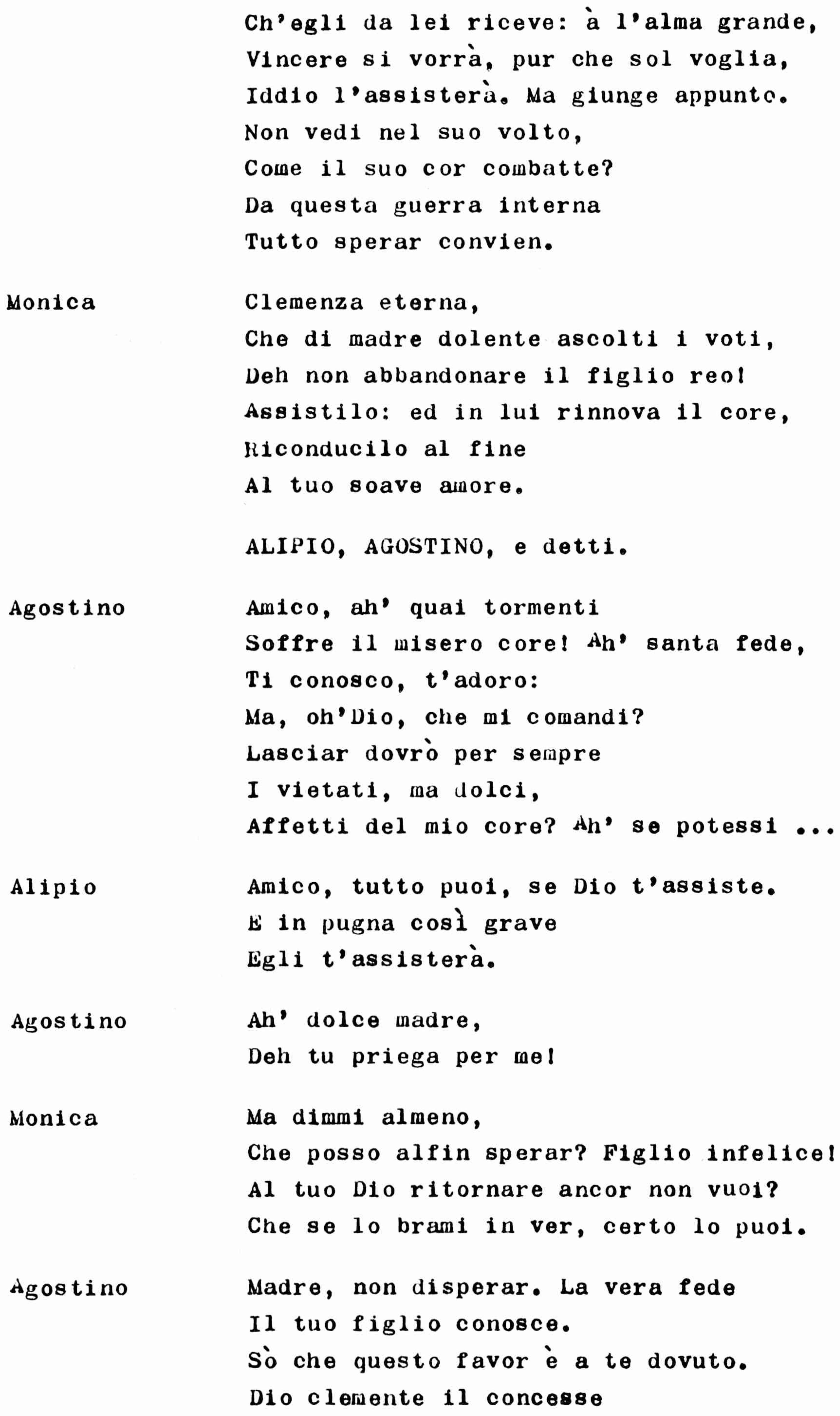


Che se 10 brami in ver, certo lo puoi.

Agostino

Monica

Agostino

Simpl1ciano

Agostino
Madre, non disperar. La vera fede

Il tuo figlio conosce.

So che questo favor è a te dovuto.

Dio clemente il concesse

A tuol ferventi voti.

Ma il core, oh' ciell ... 11 core

Lall'antico costume

Sclogliere non si puòl Deh' ancor non cessi

Di plangere, e pregar. Al tuo dolore

Non sarà sordo 11 cielo,

Concederà 11 favor del divin sangue,

Nuove forze al mio cor, che geme, e langue.

Piangeró, ma, flglio amato,

Quanto ancora del tuo fato

Farai piangermi cosi?

Prieghero, ma al dolor mio,

Alle voci del suo Dio,

Renderassi 11 core un dì? /parte/

Ah, che il mio cor giammai

Cambiar non si potrà. Troppo son dolci

Gl'oggetti del suo amore.

Dunque non senti orrore

Del tuo misero stato? E pur tu sai,

Che tali affetti il tuo dover condanna;

Sai pur, che se non sciogli

Queste infani catene,

Misero ti fai reo d'eterne perie!

Lo so. Fieno d'orrore, agghiaccio, e trowo,

Nel pensar qual m'aspetta

Orrenda eternita. Ma pur non posso

Liberarmi dal giogo,

Che vorrei detestar.

Alipio Tentalo almeno;

Niegati almen per poco al reo veleno,

Che debole ti fa. 
Simpliciano

Se amar pur vuoi,

Ama non tal divieto,

Ma degl'apfetti tuoi,

Scegli un più degno oggetto.

Dal creato ti volgi al Creatore;

Chi mai dell'amor tuo

Fù più degno di luí Dì, che non fece,

Per meritar, che a lui tu dassi il core?

Chi mai ti dimostró cotanto anore?

Agos tino

Padre, la forza lo sento

Di quel, che tu mi dici.

Ma voi non conoscete

Abbastanza il mio cor. Tanto è perverso,

Tanto ama il suo diletto,

Che altro più puro oggetto

Mai non potrà gradir. Il reo costume

Troppo, troppo è tenace,

$L^{\prime}$ amo benchè con lui non trovi pace.

Alipio

Agostino

Simpliciano

Agostino
Amico sventuratol

Non compiangermi piùl Nò, non son degno Della vostra pietàl Fuggite un reo,

Abbandonate un empio,

Che sedural potrebbe!

Alipio, Manicheo

Ch'1o ti resi, tu sai, tu sai ch'è vana, Amato condottier, questa che prendi

D1 me pietosa cura. Udite quanto

Sono indegno di vol, e pol sperate,

Se dopo aver inteso

Il mio stato infelice,

Ch'io mi possa cambiar, sperarvi lice.

Sempre sperar convien.

Come?! Se affatto

Contaminato 11 cor, da' suod prim'anni

D'altro non si complacque,

Che di folliel Se non curò l'eterno 
Alipio

Agostino

Simpliciano

Agos tino
E supremo Fattorl Se di veleno

Nutrirsi ogn'or, sol del placere in traccial So ogn'or di fallo in fallo

Corse l'anima cieca! E s'io, crescendo

Nel mal, coine negli anni,

Il ver neglessi, ed adottai gl'ingannil

Al fin ...

Taci, non piùl sonto d'orrore

Instupidire 11 cor, fremo e compiango

Il tuo inisero stato;

Non sò più che pensar. Lo strano evento

Mi turba l'alma a segno,

Cho non sò, se pietà mi mova, o sdegno. Sento orror del tuo diletto, La pieta mi move il pianto. $E^{\prime}$ confuso il cor' intanto

Che di te pensar non sà.

Del tuo stato io sono affitto,

Per te fremo, o poi sospiro,

E detesto il reo delirio,

Che sì miseroti fà. /parte/

\section{AGOSTINO, e SIMPLICIANO}

An' tu, Padre, ammutisci?! Ah, tu vuoi dirmi Che sperar più non lice!

Già t'intende 11 mio cor.

Figlio infelice!

$E^{\prime}$ di tua vita il corso

Un continuo fallirl Quel reo costume,

Convertito in natura,

Chi più vincer potrà?

Lo sò, 10 vedo,

Più speranza non v'è. Forza che basti

A scior le mie catene

Io non ritrovo in me. Vorre1, ma vani

Gl1 sforzi del voler la colpa à resi. 
Lode al ciell Questo è 11 varco, ov'1o t'attesi. $E^{\prime}$ ver, da te non puoi.

Ma tu, saggio, il conosci, e questa avviva, Conosoenza sommessa, 11 mio coraggio. Nulla 10 sperai, quando pidasti altero, Nel tuo solo poter. Che Dio resiste Ad orgoglio sì reo. Ma Dio consola Colui, che umil confessa La debolezza sua. Volgiti a lui, Lui priega, a lui domanda Quella forza maggior che tu non ai, E con l'alta sua vincer saprai.

Non abbandona mai Iddio giusto e clemente Quell'alma che fervente Implora il suo favor. Sanato tu sarai, Se in lui confidi e speri Gl'iniqui tuoi pensieri

Ti svellerà dal cor. /parte/

AgOSTINO/solo/

Si, solo a te, mio Dio, Volger mi voglio ormal, In te voglio sperar. Vita migliore, Fà, ch'io cominci alfin. Rendimi quella Felice libertà che fin' ad ora Disprezzai sconsigliato ... Ah' non ancora! Che dici, anima rea? Dunque, ti spiace Quel ben che dei bramar? Temi, che troppo Sollecito il tuo Dio, voglia ritrarti Da un così orrendo abbisso? Esser per sempre o misero, o felice E' In tua mano, e non scegli?! Ah' troppo è amaro Per sempre abbandonar ciò che parea L'unico e sommo ben. Misera vita, Trarrò privo di voi Dolci affetti del cor? Ch'io v'abbandoni? 
Ah' nòl Ma del mio Dio

Lo sdegno non paventol?

obblio l'amorl M'offre il perdon, nol curo;

Tanto per me sofert; nulla vogl'10

Sopfrir per luil si, non più dubil: Io credol

Già convinta è quest'alma -

Della voce del ciel sentì lo sprone,

oimel L'alma è convinta e 11 cor s'oppone.

Il rimorso opprime 11 seno,

Ama il core il suo delitto;

Son dubbioso e son afflitto

E risolvermi non sò.

Del mio stato gemo e peno.

Vorrei volgermi al mio Dio,

Ma da' lacci del cor mio

Come sciogliermi potrò?/in atto di partire/

NAVIGIO, e dettI

Navigio

Caro Germano, alfine

T'abbraccio con piacer. Alfin ti trovo

Rivolto a quella fede

Che beati cl fà. La glola eccede

Troppo nell'alma mia,

Per poterla spiegar.

Agostino

Ah' pena rial

Santa Pede, dover, costumi rei,

Qual guerra in questo cor vol caglonatel

Chi di vol vincerà? Alme beate,

Assistetemi voil

Navigio

Dimu1, Germano ...

Agostíno

Lasciami, per pietàl Fuggir mi lascial

Si turbato son'io

Che quel, che tu mi dic1, appena intendo;

Me stesso in tanto orror' 10 non comprendo. 
NAVIGIO, pol MONICA, indi SIMPLICIANO, e ALIPIO

Navigio

Monica

Navigio

Monica

Navigio

Monica
Perchè cosi mi lascia?!

Perchè cosi turbato

Egl1 parte da me?! Forse 11 suo core E' degli antichi affetti in preda ancoral

Dov' è il German?

Non sò, lasclomml or' ora.

Che pensa? Che ti disse?

Egli turbato in volto

Appena m'ascoltó; grave pensiero

Parmi che volga in mente.

Geme, sospira, e poi

Qual'uom da grave affanno,

O da furor commosso,

Sta sospeso, s'aggira,

Si scolora, s'accende,

Guarda 11 Ciel, guarda 11 suol, chi mai l'intende?

Come Pra venti insani

Geme agitato il mare,

Gemer cosi mi pare

Il povero suo cor.

E1 degl'apfetti umani

Misero schiavo indegno

Né sente orrore, e sdegno,

Né li detesta ancor. /parte/

E nessun 10 soccorre?

Padre, il Piglio abbandoni,

Ora che più che tnai

Egli à d'uopo di te?! Se non l'assisti,

Del suo perverso core 1 rei costumi

Certo lo vinceran. 
Alipio

Monica

Simpl1c1ano
Vidi che 1 lumi

$A^{\prime}$ di pianto bagnat1. Ah, corri a lui,

Lo rinforza, 11 consola,

Non lasciarlo cosil

Non Involargl1

Quel fortunato istante in cul Dio

Forse la voce udí.

Del zelo mio,

Madre, Pidarti puol. Men vado a lui.

Vo1 con fervent1 vot1

Ad Implorare andate

Dalla clemenza eterna

Vittoria a lui di questa guerra interna.

cono

Inspira, o Dio clemente,

A lui più degno arfetto;

Dogni terreno oggetto

Rend1lo vincitorl

$\mathrm{Ah}^{\prime}$ non sia sparso in vano

Per esso 11 Divin Sangue;

Quel1'anima, che langue,

Rinforzi il tuo favorl

/Fino delia Parte Prima/

$$
\text { Parte seo o n a }
$$

MONICA

Il figlio ancor non vedo,

Miseral Ogn'un mi lascia

Sola era tante angustie;

Só, che 11 figlio combatte,

Ma non só, s'egli vinse. Ah' Dio clemente,

T1 mova 11 mio dolorl Tremo, m'affanno, 
Palpito, sudo, agghiaccio, alcun non viene, Non mi consola alcun fra tante pene? !

Ah' veder già parmi 11 figlio Avvampar nel reo sogglorno, Ah' perchè gli diedi 11 giorno

Se cosi dovea perir!

Coń quall'alma, con qual ciglio

Rimirarlo in tanto orrore

Se di madre, oh' Dio, l'amore

M'accompagna al suo martir?

SIMPLICIANO, po1 alipIO, NAVIGIO, e detta

Monica

Simpliciano

Monica

Alipio
Simplician, che rechi?

Ch'o da sperar? Che paventar degg'10?

Ah' per pietà, dilegua il timor miol

Il figlio ancor combatte,

Ma la grazia l'assiste. Ah' questo è 11 giorno /S'el vuol/ del suo trionfo. Il mio coraggio, S'el la sprezza, è smarrito; e tutto 10 spero, S'el la seconda. Oh Diol Cosi turbato Qui giungi con Navigio?

Il figlio amato, Ahimél forse ricadde

Negli antich1 costumi?

Ah' no, vedral tra poco

Come forte resiste

A1 mot1 del suo cor; qui appresso 11 vidi,

D1 lagrime bagnato,

Plangere il suo destin. Sciolto in sospiri, "Conced1, O Dio clemente,

/Diceva rivolto al ciel/che vita 10 possa Plù pura incominciar. L'ora sia questa

Ch'10 rinasca per tel Purga, rinnova

D1 questo cor sedotto,

Padrel Signor ..."l Qui dall'affanno oppresso Più non parlo. Ma non taceva in tanto

Che l'upfizio del labbro assunse 11 pianto. 
Plange e quel pianto avviva

La speme fra 1 timori;

Come la pioggia 1 fiori

Sull'arido terren.

Sarà felice, e tutto

Avrà del pianto 11 frutto;

Or che del vero 11 chiede

Unico eterno ben.

S1mpl1ciano

Agostino

Monica

Agostino

Simpliciano
Bcco che giunge a noi;

Esso in gravi pensieri

Parmi ancora raccolto;

Ud1amo inosservanti

Ció che risolverá. Me là seguitel

Sarem pronti al soccorso

Se 11 vegglam vacillar $/ / 81$ ritirano tutti in disparte/

On' fier rimorsol

Ogni oggetto m'accusa. In ogni fiore

Si vile a sera, e sul mattin si vago,

Del mio vano piacer trovo l'imago.

Da ogn'onda, che sublime

Spinta da maggio forza in alto ascende,

Di quale sforzo à d'uopo, 11 core apprende.

Si faccia ... E 10 potró? Tanti an potuto;

Fia possibile a mel Me chem'affretta?

Vi sarà tempo ogn'ora ... E se or non vogl1o,

Chi sà pol s'lo vorró? ... Pur quest'1stesso

Convien, ch'lo voglia un dì. Si voglia adessol

Ma ti senti, alma mia, vigor che basti

L'acquisto a conservar? Come sperarlo?

Ah' Padre, in dubbio tal, deh' non lasciarlol

Eterno Nio, m'assistil

A Nio ricorre,

Non disperiam. Già cambia aspetto. I lumi

Fissa immobile in Ciel. Sembra che posto

Già se stesso in obblio,

Sia solo intento a ragionar con Dio. 
Voce

Agostino
Prendi e leggi, Agostinl

Ch'1o prenda e legga?!

Ch1 dall'alto mi parla? Intendo, intendo Il comando è divin. Leggasi. I fogl1 Quest1 pur son che delle gent1 il grande Apostolo vergò? Si. M'offre 11 Cielo Forse in essi un soccorso. Ora, o mio Dio, Or di tua luce all'alma un raggio splenda, E gli Oracoli tuol chiari mi rendal/legge/

Oh Infinita bontàl Chiaro or conosco, Sol tua percè, cio che mi parve oscuro. Veggio il cammin sicuro

Dalla tua legge aperto, e veggo 1 rischi

Del Pallace piacer. Convinto io sono,

Che quello sol fellct

E beati ci fa. Che folle questo

Che deboli ci rende,

Che tutto ci promette e nulla attende. Si, si, ti sieguo, o mio sostegno, o mio Pletoso condottierl Gli antichi affetti Son già pronto a spogliar. L'impresa è dura, Ma tu m'assisti e teco

Io 10 vogl1o, e 11 potrò. Le mie promesse

Oda la terra, 11 Ciel: Viver vogl'io

Sempre per te, mio Dio. Da quest'istante

Tutto a te mi consagro, e le lusinghe

D'ogni piacer funesto,

Che da te mi allontana, odio e detesto.

Navigio

Il german trionfò.

Monica

Non più dimora:

Corriamo a luil

Simpliciano

Non s'interrompa ancoral

Agostino

Mio Dio, qual cambiamentol

Per me si fà dolcezza ogni tormento. or mi pento, oh Dio, che tardi Ad amarti incomincial; 


\section{Or condanno, e tu lo sal, I deliri del mio cor! \\ Ah' pietoso, a me consenti \\ Un de' teneri tuoi sguardi \\ Che conforti, che alimenti, \\ Che avvalori il nuovo anor! \\ SIMPLICIANO, e detto, poi tutti}

Simpliciano

Agostino

Simpliciano

Agostino

Simpl1ciano

Agostino

Simpliciano

Agostino
Ah' Figlio!

Ah' Padrel alfine

Mi rendo a te. Son'io

Qual mi volesti alfin. Pitorno a Dio.

I tuol sensi ascoltai. Ben cominciasti;

Ma se troppo ti fidi, è la vittoria

Meno intiera e sicura. In te ragiona

Ora un fervor ch'intiepidir potrebbe.

Chi sà ...?

Nò, Padre, tanto

Sento canbiato 11 core

Che quel ch'amal fin'or m'inspira orrore.

$A$ un Dio cosi clemente

Sempre fedele sarò. L'amo, l'adoro;

Altro più non desio

Che di viver per luil

T'Ingann1 forse

Troppo fidando in te.

No, non m'1nganno

Temo la mia Placchezza, in Dio confido

E potró tutto in 1 ui.

Come tant'anni

Tra le colpe trascorsi

$T$ 'accingi a riparar?

Di me temendo,

Confidandomi in lui. Plangendo sempre,

Con rossor rammentando 1 giorni rei, 
Implorancio perdono a' fall1 miel.

Simplic1 ano

Agostino

S1mpliciano

Agostino

Monica

Agostino

Al1pio

Agostino

Navigio

Agostino

Simplićiano
Li se per lut dovessi

Grave pena soferir?

Qual pena è grave

Ad un reo qual'io son? Non v'è sventura

Terribile per me, pur che al mio Dio

viver possa 1 miei giorni.

A questo seno

Or vieni, o figliol Or trionfasti appienol

Fì del Ciel la vittoria.

or t1 ritrovo,

Figlio dilettol Al mio materno core,

Dopo tanto dolor, qual gioia arrech1?!

A te deggio gran parte

D1 si lieto momento.

Parlar non posso, o mille affetti io sento.

Quant', o German, s'accresce

Nella tua la mia gioial

In quel trionfo

Parmi di trionfar.

Da quale stato

M1 trasse 11 mio Signorel Oh me beatol

Si rendi grazie a Lul che 11 proprio Sangue Verso per farti degno

Di tanti doni suol che nel cimento

$T$ 'assiste, ti conduce. Alme infelic1,

Che del peccato ancor portate 11 peso,

La clemenza adorate

Del vostro Redentorel $\mathrm{EI}$ vi propone

Agostino in esempio. Egli soccorre

Ogn'alma che da vero

Brama vincer se stessa. A lui correte, 
Senza indugiarl D'un suo pietoso sguardo Degno non è chi al pentimento è tardo.

A Dio ritornate,

Lasciate l'errorel

Lo merta l'amore

Che a voi dimostrò.

Vi brama - beate,

Vi chiama - alla vita,

La strada smarrita

Col sangue ei segnò.

Coro

Si lodi 11 Ciel pietoso

Che infuse in Agostin la Porza, 11 lume, onde in santo à cangiato il reo costume. Avvalori l'esempio

Ogni timido corl Grazia non manca

A chi brama spezzar le sue ritorte, L se forte esser vuole, ogn'uno è forte.

IL FINE 


\section{/J. A. Załuski/}

N A W R Ó C E E N I E

Melodramma

Śpiewane w Kaplicy Królewsko Elektorsklej Drezdeńskiej, w Sobotę Wielka Roku 1750. Po Włosku Anonime napisane w Dreźnie przez NAYJAŚNIEYSZA KRÓLEWICZOW Jeymé POLSKA. Na noty muzy'salne przeformowane przez J. P. JANA ADOLFA Hasse Kapelmaistra Jego Krolewskiey Mci. á z Włoskiego metru ná wiersz oyczysty przetłumaczone Przez J. Z. R. K. W Kielcách 21.23. y 24. Febr. 1751 .

INTERLOKUT OROWIE :

Sw. Augus tyn

Symplicjan

Sพm. Monika, matka świętego

Alipiusz przyjaciel Jego

Nawigiusz brat Augustyna

Aniol

Chór cały muzykantów

C z ę ś ć p i e r w s z a

SYMPLICJAN I MONIKA

Symplicjan Matko smutna, strapiona przez zbytek kochania, Zaniechaj kiedyszkolwlek płaczu 1 ślochanial Syn twój tchnie żywa wiarą, a gdy jarzmo Fana Przyjmie rozum, to serca już pewna odmiana.

Monika

Achl Achl słaba stad, ojcze, nadzieja; wiadome Jest mi dość serce syna. Zawsze wiarołomne Zwykło bywać. Coraz go marność śwlata c1ska, Coraz go w przedsięwz 1 ęciu strzymuja 1 grzyska Świata tego, marności juz zaprzątnęły To serce. Lłe nalogi juź górę wzięły I jakze się spodziewać? Serce znikomościa Oziçbione, by pałać JĹZUSA iniłościa Mitalo. 
Symplicjan

Prawda, wiele odwagi, więcej jeszcze męstwa Do takiego nad sobą potrzeba zwycięstwa, Lecz za cóz powatpiwać 1 nadzieje tracié? Czyż nie masz mocy wiebie, coby ubogacić Mogła Syna odwaga? Jako łzy wznieciły Swiatıo wiary w nim twoje, tak będa gromiły Pychę jego. Od czego BóG, ze płonna wiara, Gdy się przykazań Boskich zachować niestara, Obaczy kiedyszkolwiek, zechce przezwyciężý Wola, bo ma wspaniałe serce. A zwycięzyć Sam mu BÓG dopomoże, byle chciał z ochotą Szczera 1 nieomylna. Lecz co widzę? oto Sam właśnie nadchodzi. Patrz, z postaci twarzy Zmiarkujesz, ze sie walka w sercu jego zarzy. Z tej to wnętrznej utarczki spodziewac sie trzeba, że dopomagać, że mu sprzyjać będą Nieba.

Mon1ka

Ach! BOże miłosierny, Syna nie porzucaj, Przybywaj inu na pomoc, dróg twoich nauczaj, Wysłuchaj utrapiona Matke. Niech odrodzi W nim sie serce juz w cale nowe. Niech odwodzi Miłość Twoja od ziemskich rozkosz myśl iserce.

\section{ALIPIUSZ, AUGUSTYN 1 CIŻ NA USTRONIU}

Augus tyn

Ach! achl ach! Przyjacielu, wakiej poniewierce To me zostaje sercel Jak sie bardzo dreczy! Trudno c1 to wyrazić, Jak się trapi, męczy. Wiaro święta, poznawam Cię 1 adoruje; Lecz, o Boze, wola Twa cóż mi nakazuje? Bym zaniechał rozkoszy śwlata? Czyż pozbędzie Serce me iniły nałóg? Duszkoszby ...

Alipiusz BóG wszędzie

Stanieć z pomocą; ręczę. Ten ci dopomoże W tej bitwie. Laska chęc zła do grzecinu przemozo. August yn Ach, miła Rodzicielko, racz mię Lodlitwami Twemi odrodzić BOGU! 
Augustyn

Monika

Augustyn

Symplicjan

Augus tyn
Memi rzucasz? Już powledz prawdę, nieszczę́liwy Synu, czy się już wrócić do BOGA masz chciwy Umysł. A jeśli pragniesz bardzo 1 szczerze, Upewnian, że potrafisz.

Nie trwoż się w tej mierze, Matko, o mnie! Już poznał Syn twój wiarę prawą, Którąś ınu uprosiła niejeduá Łzą krwawą. Wiara prawa jest we mnie skutkiem Twej modlitwy, Ale serce, ach serce, poprzestać gonitwy

Za natogami swemi dawnemi nie moze.

Jeszcze się módl. Jeszcze płacz. Na te pró́by, Bożs, Nie stulisz uszu. Syna Twego Krew 1 męka

Niechaj me zmocni serce, co jęczy, co stękal

Synu, płakać będe chętnie,

filez pókiz tak żyć smętnie?

Pók1 łzy lać będę moje?

Chcę sie modlic, lecz na troski

Moje kiedyz na głos Bosk 1

Ocuci sie serce twoje?

Ach, ach, juź widze serce, choć po wielkiej chwile Nie odmient sie nigdy? Bo mu krotofile

I doczesne rozkoszy zbyt zasmakowały.

Takze opłakanego, o zapamiętały, Nie znasz stanu twojego 1 niebezpieczeństwa?

A wszakze wiesz, ze wszelkie wiara wszeteczeństwa Potępia. Wszak wiesz dobrze, że jeśli te więzy Nleuczciwe nio stargasz, karan będziesz cięzy Wiecznie piekiel nych mękachl

Wiem to nal eżycie.

Ach, truchleje, martwieje, odbiega mie życie, Gdy sobie nieszczęśliwa wieczność, co mię czeka, Przed oczy stawiam, ale nędznego człowieka Rozkosz opanowała tak mocno, na trwoge Że bynajmniej nie dbając, porzucié nie moge Jarzmo słodkie. 
Alipiusz

Symplicjan

Augus tyn

Alipiusz

Augustyn

Augus tyn
Przynajmniej choć przez krótka chwilę

Spróbuj się a rozkoszy rzuć 1 krotofile;

oddal się choć do czasu od jadu, co truje.

Nie możesz-1i nie kochać. Kochaj, nie hamuję, Ale alektom twoim obierz cel godniejszy.

Do Stworzyciela afekt nierównie zacniejszy

Niźl1 chęć do stworzenia. Kto bardziej kochania

Twego godzien? Powiedz! Czyz nie czyniz starania BÓG wszelkiego, byś w sercu ustappił mu prymu?

Kto kiedy tak pokochał mocno kogo? Czy mu

Serca odmówisz?

ojcze, co mi powiadacie

Przyznaje, serca mego lecz jeszcze nie znacie:

Tak jest zepsute, tak w nim przewrotność się mieści,

Tak zbrodnie własne głaszcze, w występkach sie pleśc1, Że prócz zbrodni i nnego nic mu nie brakuje. Nałóg tak wziąz górę, że lubię, co mi truje Tego spokojność serca.

Żal mi Cię, niebożel

Ach, nie żałuj mię więcejl N1c mi nie pomożel Lalu twego nie jestem godzien; winowajce Zaniechaj 1 nieszczęściu swemu zostaw zdrajcę, Ten by cię zwieść potrapiz. Mój Alipiuszu, pomnij, żern cię za sobą wciągną az po uszu W błędy Manicheusza, więc porzuć starania O mnie zdesperowanym, od opamiętania Dalekim! Wprzód posłuchaj, mój nauczycielu, Jak nie jestem twej godzien opieki, jak wielu Zbrodni zostaję wig̨źniem. Ze pieczołowania Twego nie zasłuzyłen - przyznasz - 1 kochania. Lepiej, radzę, przeniknij serca mego głębi A uznasz, że twe serce płonne trudy gnçbia o moim nawróceniu.

Tracić nie należy

Nadziei nigdy.

Jakze! Jeśl1 serce bieźy 
Alipiusz

August yn

Symplicjan

Augustyn
Ku zbrodniom rozkiełznane? Jeśli od dzieciństwa Nie do cnoty chęć miało, lecz grzechu szaleństwa, Jeśl1 o Stworzycielu mając zaniedbanie, W stworzeniu, w cielesnościach miało spodobanie. Jeśli się jadem zbrodni ustawnie tuczyła Dusza, z grzechu do grzechu oślep przenosila, Jeśli sie równo we mnie złość krzewiła z laty, Obłuda miejsce brała prawdzie dla prywaty, Nakoniec ...

Juz dość tego, serce mi omdlewal

Nad twy

Nie wien, co myśleć dalej, mieszam się sam w sobie. Nie wiem, czy złość, czy litość wzrusza mię ku tobie. Wstręt ini Twe zapamiętanie Sprawuje, litość ślochanie, Gdy to sercu pomieszanie, Jakież mieć o tobie zdanie?

Trapisz mie $w$ tym biednym stanie. Raz strach przejmuje, raz wzdychanie. Ach, przeklęte przywiazzaniel Swiata gubi cie kochaniel/odchodzi/

\section{AUGUSTYN I SYMPLICJAN}

Ach, Ojczel nic nie mówisz! Ja czytam milczenia, Że już dla mnie nadzieja upadła Zbawienia. Juź sie dorozumiewam, co milczenie znaczyl

Ach, Synu nieszczęśliwy! przyjdzie do rozpaczy! Bieg cały życia twego jest występkiew jednym. Zły nałóg przemieniony w naturę jak biednym, Achl jak cię czyni, trudno wypowiedzieć

$$
\text { wcale. }
$$

Widzę i wiem zupełnie. Juz Nadziei "vale" Powledziec mi przychodzi. Moc moja mi wzlęta, Siły wattıe nie zinogit, bym potargać peta Ldołał. Radbym chciał, ale w tej ciezziej niedoli Grzechy opanowały moc, site mej woll. 
Chwała BOGU, tu termin, gdziew na cis pilnowałl To prawda, że nie zmożesz, choćbyś usiłował, Sam przez siebie. Mądrze swa słabość sain wyznajesz, Lecz tyrn sanym juź dobrit otuchę mi dajesz

o przyszłym nawrócentu. Pókiś własnym dufał Siłorn, jam powatpiwał, bynajmniej nie ufal Tak BÓG tłumi nadętą pychę; ucho daje Temu, który pokornie niezdolność wyznaje. Rzuć się do tego Pana! Nieś do niego modly, A uznasz, że się mocnyin staniesz, coś był podły, Jego mociz zmocniony, jego siłą wsparty

Wlot zwycięzé potrafisz świat, ciało 1 czartyl

Nie odrzuci z swej opieki

Miłosierny BúG na wieki

Juszę tę, której gorliwa

Prośba Jej łask1 wzywa.

Uleczona duszy rana,

Ufaj, będzie z laski Pana.

Ten wątpliwość myśli twojej

Wyrwie, którać serce dwoi.

AUGUSTYN /sain/

Tak, tak jest, o mój BOŻE, do samego ciobie /Urając w tobie sanym/ chcę obrócić siebiel Daj mi łaskę, bym lepize odtąd zaczal zycie Na Twolej słuzbiel Ale prosze mianowicle, Abyś mi wrócić raczył te wolnośc szczęśliwa Którąm - nieszczęsny - dotąd wolą niegodziwą Gardził. Ale poczekaj jeszcze na to, Paniel Ach, co mówisz, ma duszo? Ach, zapaintętanio Jakie Twoje w tej mierze 1 także nie żądać Przychodzi ci to dobro szczególnie pogląać, Na którebyś powinna 1 także z złej toni By cie nie wyrwal ten Pan, co zwykt na swej dłoni Milec tonących, zbyt prędko, lękasz s1e 1 chronisz? W twej mocy jest szczęśliwym lub być nędznyml

I powatpiwasz jeszcze, co masz obrać raczy? /stronisz? Niech sie we mnie natura sama wprzód obaczy. w nowego sie oblekz człekal Czyz to mozna, 
By porzucić na zawsze ścieźke tę, co zdroźna Dotąd szczególnie z moim gustein się zgadzała? Za jedyne me dobro miana, suakowała? Tak, że z was ogołocon, namiętności miłe, Man się wyrzec na zawsze was 1 o mogile Równo z sobaz uderzyćl darmol niepodobnal Widze, ze sie natura wzdryga niesposobnal Tak że się gniewu, zemsty BUGA nle obawiam? I takze Jego Miłość przed oczy nie stawiam? Przepuścić przyobiecał. Ja od niego stronię. Laske mi obiecuje, a ja nie dbam o nie. Tylo dla mnie ucierpiał! Ja cierpieć dla Pana I odrobiny nie chcel Ach, Juz przekonana Dusza moja zupełnie. Juź wierzę. Już wszelkie Od siebie precz odrzucam watjpliwości wielkiel Czuje w sobie Boltigo natchnienia ostrogi. Ach, duszać przekonana, lecz na serce trwogil

Sumienia mię robak gryzie, W kaz grzechowy serce liziel Walcze sam z sobiz troskliwy, Lecz w odwadze zbyt leniwy. Stan mój dręczy mię zbyt smętnie. Miałbym się do BOGA chętnie, Lecz jak stargać mocne pęta, Ach, rzecz mi jest niepojeta.

/Nawigiusz nadchodzi i nowi/

Bracie arcy kochany $!$ Sclskara, mile witam. Widzieć cię, sobie wielkie za szczęście poczytaml Z twego do prawej wiary nawrócenia, czuje Radośc tak wielką, że ją darmo usiłuje Wyrazic.

Augustyn Ciężką mękę, wiaro święta, znoszę• Przykazań, złych nałogów utarczke ponoszę. Jak nieznośna ta walkal Ach, jak serce dwoi. Ach, jak krwawym się potem czoło moje znoil Kto z was kto juz zwycięzy? Swięte niebios duchy, Przybywajcie na pomocl Dodajcie otuchy, 0 , wygranej nad ciałem duszy! 
Augustyn

Naw1giusz

Monika

Nawigiusz

Monika

Nuwigiusz
Darmol Daj mi pokój, proszę,

Puśc mię, bom jest tak srodze w soble pomieszany, Że nie słyszę, co mówisz! Bracie mój kochany, Sam siebie nie poznawam!

\section{/odchodzi/}

NAWIGIUSZ, PO TYM MONIKA, PO TXM SYMPLICJAN I ALIPIUSZ Ode mnie odchodzi?

Bardziej od siebiel To mnie zmięszanie obchodzil Musi być, że z nim serce sporne, krnąbrne, toczy Wolną bitwę.

Gdziez Brat jest?

Nie wiem. Tu przed oczy

Memi dopiero stawał.

Co mówi? Co myśli?

Coś mi niepojętnego w zamysłach swych kryśli. Ledwie słuchał. Głęboko w myślach zatopiony Narzekał, wzlychał, niby strachem przerażony, Czy furya zdjęty. liaz kręciz się; jak wryty Wlot stanął, opanował smutek go niezbyty. Raz na niebo, drugi raz w ziemie, na przemiany Patrzał. Trudno wyrazić, jak jest pomieszany.

Jak burzliwe morskie waty,

Gdy "Eurus" wzruszy zuchwały,

wyją, rycza, tak też jęczy

Brat, gdy serce zal mu dreczy.

Czuje się być nievolnikiem

Grzechów, chuci hołdownikiem.

Brzydzi stę tylai, lecz jonęta

N1e dozwala targá pęta.

Monika

Tak ze nikt nie ratuje? Ojczel Takze Syna Opuszczasz właśnie, kiedy nadzieja jedyna Jego w tobie, najwi gkszej wymaga pomocy? Jezli mu niedoradzisz, to moc ciemnej nocy Naniętności, nałogi przezwycięziq wcale. 
Symplicjan

Monika

Symplicjan
Widziałeri, ze miał oczy zapłakane, ale

Ty jako Matka zu nim biez co prędzej, strzymuł

W przedsięzięciul Pociesz gol A rozpacz zatrzymuj! Nie zostawuj go, jak jest, bez rady!

\section{Otucha}

We mnie taka, że Bosk1 głos teraz Syn słucha, A zatem przerywać go wcale nie należy.

Spuść się, Matko, na moja gorliwość ot, bieży Symplicjan do niego. Teraz na kolana Padnijcie, a błagajcie Niebleskiego Pana, By w tak cięzkiej utarczce zmocnił jego męstwo, A z namiętności dał mu zbawienne zwycięstwo.

\section{CHORUS}

Miłosierny Boze, Panie! Wskrzes w tym sercu Twe kochaniel Niech potęga ciał a więzy, Swiat i czarta niech zwycięży! Ach, zań darmo Krew wylana Niech nie będzie Zbawcy Pana! Niech tu dusza jego wsparta Laska ujdzie sidel czartal

$$
\text { C z ę śc d r u g a }
$$

Monika

Syna jeszcze nie widzę l Matkę utrapioną Odstępują już wszyscy w uciskach znędznioną. Wieli, ze Syn walczy, lecz nie pewnam, że on duszy W tej sie stanie utarczce. Ach, niech cię poruszy, Miłosierny Bożel Lal mój nieporównany, Drżę, lq̨kam się. Potnieję. Stygrię na przemiany? Nikt nie przybywa, nikt swą przytomnościa wczesniz Nie cieszy! B(OLL, pociesz, ach, Matkę bolesną! Tak mi siq zda, ze w upale riekielnym Syn gore w cale. pocózem ten płód wydała Na świấ, gdym postradać miała? 
Jakim sercein, Jakim okiem

Nad tym sie stawie widokiem?

Matkasz będzie wiecznie jeczyc,

Syna że ma wieczność dręczyć?

MONIKA, SYMPLICJAN, PO TYM ALIPIUSZ I NAVIGIUSZ

Monika

Sympl1cjan

Monika

A11pius2
Co mi tam pociesznego niesiesz, bym juz stękać Przestaza? Czego sie mam spodziewać, czy lezkać? Ach, zmiłuj się, co prędzej ulzyć bojaźn srogąl

Syn twoj jeszcze walczy, lecz laska Boska droga Prowadzac go zbawienna zmacnia Jego siky. Dzień dzislejszy/by tylko chcial/będzle mu miły, Będzie mu dzień Tryumful Jezell pogardzi Ta zaska, zdesperować przyjdzie coraz bardz1. Jezel1 zaś instynktów tej łaski usłucha, Dobra o nawrócentu będzie nam otucha. o Boze, jak z Nawigim chodzi pomieszany!

Przebógl Syn się podobno do swej uglaskanej Namiętnośc1, pleszcz onych powróc1 nałogów?

Nie powatplewaj, ze swych namietnośi bogów Ze swego wyruguje wlot serca. W tej chwili Widzlazem, ze nad swolm stanem płacze, kwili. Westchną głębokol Patrząc wiebo z temi słony Daz się słyszeć: "O Boze, przybytek gotowy Obierz sobie w mym sercu, czystości dogadzac Bym mógl, spraw to laskawiel Niech mi sie odradzac Przyjdzie na nowa słuzbe Twoja, Ojcze, Paniel" A to rzekszy 1 ciezkie r:-lawszy waychanie Ucicht, atoli wcale nie zamilkt, "wylanie Lez rzesistych znaczy wiec to, co warg ruszanie". Slocha? Z płaczem sie dobywa Coraz $w$ trwodze ufnośc zywa, Kwiat tak sie ozywia snadnie, Gdy na suchy grunt deszcz spadnie, Weźmie skutek znaczny pewnie Z lez, co lch wylewa rzewnio. Bo 2 pokorna ząda modła Od BOGA, co dóbr jest zrodzo. 
Symplicjan

Augustyn

Monika

Augustyn

Symplicjan
Oto sie juz Augustyn zbliża. Tu przychodz1, Lecz umysi zatopiony w głębi myśli brodzi. Podsłuchywajmy, jakie weźmie przedsięwzięcie. Przybędziem mu na pomoc, jeśli go w odmęcie Myśl1 wahających sie obaczem.

Jak gryzie

Ilobak sumienia serce, gdy trzymać chce w ryzie Wszystko, co tylko zmysłom podpadal Mie wint! ni W kwieciu, co ranek wdzięcznym, wieczór zwiędłym czy Widzę obraz mych rozkosz? Silnie ów, co zgania w Lontanach wody, w góre 1 gwałtem nakłania, W która chcę stronę "Tłuczek" z metalu ulany Za wrór sobie, ach serce, miej do tego dany Żé podobnych sil trzeba, bierzze miare sobie, A to czyńmy, co czynić w tej należy dobie. Alez czy zdołan? Fozakze potrafiło tylel Toć 1 po mojej ta rzecz będzie przeciez sile. Ale kto mié tak nagli? ... Pomyślemy o tym Przy wolniejszej chwile ... czas begdzie temu po tym. Ale jeśli nie zechce teraz, w tym tu czasie, Któz mię upewni, lzć zechce mi sie zasie? Więc sie teraz niech zechce, co chcieć właśnie trzeba Kledyszkolwiek ... Teraz chcleć jest nagła potrzebal Lecz, Duszo, czy masz ktemu siły? ... Utrzymywać Byś mogła przedsiewzlecie?! Soble obiecywać Tego, czyć jest podobna?

Ojcze, nie odstepuj

W tym go powgtpiewaniul

Na pomoc przystepuj,

Boze wiecznyl

Co słyszę? Juz oto BogA wzywa. Dobra nasza juz we mnie tkwi nadzieja zywa, Że sie teraz nawróc1. Mini mu się lice, Jak w tecze tak ma w nlebo wlepione źrzenice. W kontemplacyjnym, gdy juź zachwycentu, powie Kazdy, ze juz o sobie zapomniaz, w rozmowie Z Bogiem samym zostając. /Głos a N1eba Antelski/ 
Augus tyn

\section{Weź to p1smol Czytaj!}

Zdami sie - ten głos z niebios. Już że go poczytaj

Za rozkaz Boski sobie ... Nie watp, Augustyniel

Czytam, widzę, że to sa pisma tego, słynie

Co po wszystkich narodach Pawła Apostoła

W nich mi Niebo podaje snadź pomoc, co zdoła.

Więc mi, Boże, spuść światła Twojego promienie

A objaśniej wyroki twoje 1 twe chcenie.

Ach, dobroć nleskończonal Poznawam Cię iście:

Co się tajno zdawało dotąd, oczywiście

Juz widzę: widzę bity gościniec twej woli,

Widzę oraz 1 zmyślne ścieżki tej niedoli,

W która mię namiętności wprawiły fałszywe.

Uznaję chętnie Prawo Twe za światło żywe,

Które to nas jedynie zbawia. obiecuja

Nam coś roskoszy świata, lecz nie dotrzymuja.

Są to łudzące cacka, próżne omamiente,

Co wiodiz ułudzonych w wieczne zatracenie.

Już, juź idę za tobą, prawy Przewodniku!

Litościwy zbłąkanej duszy miłośniku!

Jużem gotów poprzestać szkaradnych nałogów!

Już, Jużem gotów powstać z grzechowych barłogów!

Prawda, że wielka czynie imprezę. Pomocy

Twej jednak pewien, $i$ chcę, 1 co chce, to mocy

Mojej będzie. Niebiosa, słyszyciel Niech głucha

Nie bęuzie zieala, co me przedsiewzięcia słucha:

Poprzysieggan, o BoLk, żeć służyć jedynie

Chcę odtaqd. Grzech, co gubi, niechaj wiecznie gint

Wyrzekali się rozkoszy, z namiętności szydzę.

Złe nałogi potępiam, grzechami się brzydzę.

Nawigiusz

Mon1ka

Symplicjan

Augus tyn
Brat zwyci ̨̧zył Juz w cale!

Już bieżmy do niegol

Jeszcze go nie przerywaćl

Boze, serca megro

Jakif w soile oulntanę czuję! Twe to dziło -

Co było przyiro, teraz staje lai sie milol 
Zal mi, późno żeln poznawał

Ciebie, BożE, nie oddawał

Dawniej serca. Wszeteczeństwa

Wyrzekam się. Wstyd szaleństwa.

Wejrzyj na mnie litościwym

Okiem, bądź mi miłościwym!

Jedno oko da wejrzente

Noc, siłę, miłość, zbawienie.

SYMPLICJAN, AUGUSTYN, POTEM WSZYSCY.

Symplicjan

Augustyn

Symplicjan

Augustyn

Symplicjan

Augus tyn

Symplicjan

Augus tyn
Ach, synul

Ach, ach, ojcze, już ci się oddaję!

Masz mię takim, jak chciałeśl Bogu się poddaję.

Słyszałem przedsięwzięciel Dobry jest początek, Lecz, jeśli zbytnie dufasz, niepewny to wziątek! Owszem - pewna przegranal Gorliwość, nieboze, Tl1 sie w sercu, lecz z czasem ta ostygnąć może, Kto to wie?

0j, nie, 0jczel Serce mam zmienione:

Co sie przed tym lubiło, teraz mi zmierzione.

Chęć ku tak łaskawemu BOGU, nieustannie

Wierna we mnie Jemu część; On moje kochanie!

I dla tego szczególnie dalej życia żądam,

Bym zył dla nlego wcale, póki nie oglądam ...

Cay nie mylisz się przecie, gdy tak wcale sobie Dufasz? !

Owszem, nie ufam ułomnej osobie!

Słabości się mej lękam, lecz w BOGU nadzieję Pokładali, z nim dokażę wszystko.

A złe dzieje

Tylu lat, jak poprawisz? Lat, co przepędzone W grzechach!

Poprawię siły swe kładąc na stronę, W BOGU kładąo nadzieje. Płacząc zawsze, wszędy 
Przypominając z skruchił dawne swoje błędy, Prosząc, żebrząc o grzechów zbrodni odpuszczenie.

Symplicjan

Augustyn

Symplicjan

Augustyn

Monika

Augustyn

Alipiusz

Augustyn

Nawigiusz

Augustyn

Symplicjan
A gdybý́ mial dla BOGA Jakie utrapiente Znosić, czy byś się na to odwazy $¥ ?$

Kat ownie

Czyż uoga byé tak srogie, by nie był nierównie Mój grzech sroźszy i cięzszy? Nie masz takiej męki, Coby zrównała moje ku BOGU niewdziękil

A te tak siła razy popełniłeml Trwoga Już u mnie nie ma miejscal Bylen zawsze BOGA Mego kochał, słuzy mu, czasu nie mitręzy Na swiatowych rozkoszach $\ldots$

Jużeś, Już zwyciężył

Przystąp, bym cię uściskał winszując wygrany!

Nie ze mnio, lecz jest z nieba ten tryunf mi dany. Ach, Jaka strapionemu sercu ulgal Miałam Co cirpić przez lat tyle, atoli juz wcale Ustapiły, w radość sie przemieniwszy, zale.

Przypisuje ci skutki mej pociechy chętnie.

Mówić nie moge! Radość sercu niepojętnie Gośc1 1 nie pozwala mowy, tłumi słowa.

Z tej pociechy, kochany bracie, we mnie nowa Wzbudza, mnoży sie radośćl

Ach, zwycięstwo twoje

Tak mię cieszy jak własnel

Co za szczęście mojel Ach, z jak niebezplecznego wyrwałes mię, Panie, Stanul

Dziękowac trzeba Panu nieustannie, Le Krew whasná na Krzyżu hojnie toczyé raczyl, By cię godnym tak wielu darów swych przeznaczył, On potyczce pomagal, on cie dotad wodzi Własną ręką na droge szczęśl1wą, on rodz1 
Wszystkie wercu zbawienne myśl1. Dzięki dajcle, Dusze w jarzmie jęczące grzechul Wychwalajcie Nieskończone Bożego miłosierdzie Syna, ze wam przykład osoble daje Augustyna! On kazdemu sił doda 1 mocy użyczy, Kto tylko szczerze soble tryumfować zyczy. Ach, garncie się do niego, boć jest miłościwyl Miłosierdzia nie godzien, kto walu leniwy. Nie godzien jest Boskiego wzgledu, kto za grzechy Nie czyni do pokuty swej wcześne pośpiechy. Ach, wróć się, duszo, do BoGA Mylna, co nią chodzisz, drogal

M1łość Jego zasłużyła, Abyś w słuzbie jego żyła. Szczęśliwym cie wiuzieć zgoła życzy, do swej chwały woła, Bý́ na prawa droge baczył, Własną ściežki krwią poznaczył.

CHORUS /alias wszyscy razem śplewają/ Dajmy Niebom dzieki, chwały, Ze 1 moc, i światło wlały W Augustyna, co nałogi Odmieniz w obyczaj drogil

Bojaźliwe serce, śladem

Chodź Jego, rządí sie przykłademl Laski nikomu nie zbywa;

Kto chce mocnym być - ten bywa.

Ad M. D. G.

Me1 et proximorum Conversionem

Arstęp, opracowanie 1 przygotowanie do druku .Bazy 11 Degórski OSPPE/ 